\title{
Petrás, Éva. 2019. Álarcok mögött. Nagy Töhötöm életei ('Behind Masks: The Lives of Töhötöm Nagy'). Budapest-Pécs: Ábtl-Kronosz. 308 pp.
}

\section{Reviewed by Susan Glanz, St. John's University}

Éva Petrás spent years researching, examining and trying to understand the reasons for the twists and turns in the life of Töhötöm Nagy (1908-1979), a Jesuit priest, a layman, a freemason, an author, and a collaborator with the American Office of Strategic Services (OSS, a predecessor of the Central Intelligence Agency, CIA), and from the mid-1960s also with the Hungarian State Security Service or Secret Police. Nagy was born Aleksandrovo (presently in Serbia) in a Transylvanian Szekler (Székely) family, and after graduating from high school he began his university studies in Budapest. In 1926, feeling a call to priesthood, he left the university and joined the Jesuit Order and was ordained in 1937. Although he was an average student throughout his studies, he had outstanding organizing and writing skills. These talents were recognized by his superiors and he was appointed to the leadership of KALOT, Katolikus Agrárifjúsági Legényegyesületek Országos Testülete ['National Association of Catholic Agrarian Young Men'], a Catholic Youth Movement of Agricultural Workers. KALOT's goal was to preserve folk traditions and Christian morality and to teach leadership skills to agrarian youth. KALOT members studied rural life, especially that of the poor, and for that goal they organized lectures and courses. KALOT was an extremely successful organization and by 1942 it had half a million members, but in July 1946 it was dissolved together with other Catholic youth associations. KALOT and Nagy believed in the intertwining of social progress and Catholic faith and advocated for agrarian reforms. Toward the end of World War II, Nagy's identification with KALOT's goals led him to look for ways to revive the organization, which was then forced to go underground with the German invasion of Hungary. To achieve this aim, in late 1944 he began a new career as an ecclesiastic diplomat. He travelled to Debrecen to meet with the Russians and the Interim Hungarian Government and received permission to restart the organization.

At the end of the war, when the Holy See recalled the papal nuncio from Budapest, Nagy took it upon himself to travel to Rome to inform the Vatican of the position of the church in Hungary. In the two years after the war Nagy travelled to Rome several times, always incognito and with grave danger to himself, with the goal of presenting to the Vatican reports on the status of the Hungarian Catholic Church. Nagy was a messenger and a source of information not only for the Vatican but also for the Italian and Austrian branches of the OSS. Nagy recommended József Mindszenty, Archbishop of Ezstergom, to become the State's Archbishop, and in return he

*zsuzsa19745@gmail.com

(cc) $\mathbf{E Y}$

ULIS D-Sorke
New articles in this journal are licensed under a Creative Commons Attribution 4.0 International License.

This journal is published by the University Library System of the University of Pittsburgh as part of its D-Scribe Digital Publishing Program and is cosponsored by the University of Pittsburgh Press 
Glanz, Susan. "Petrás, Éva. 2019. Álarcok mögött. Nagy Töhötöm életei ('Behind Masks: The Lives of Töhötöm Nagy'). Budapest-Pécs: Ábtl-Kronosz. 308 pp." Hungarian Cultural Studies. e-Journal of the American Hungarian Educators Association, Volume 13 (2020) DOI: 10.5195/ahea.2020.399

hoped to become Mindszenty's advisor. While Mindszenty did become Archbishop and thus the leader of Hungary's Catholic Church, Nagy did not receive the appointment he had hoped for. The relationship between Nagy and Mindszenty deteriorated very quickly, and Mindszenty withdraw his support from KALOT and opposed the goals of the newly organized Christian Democratic Party, in which Nagy was also involved. In addition, Mindszenty pressured the Jesuit Superior General to send on a mission and practically exile or banish Nagy to South America.

Nagy's first post was in Montevideo, Uruguay, where he wanted to start a youth movement similar to the Hungarian KALOT. But the conservative Cardinal Barbieri of Montevideo asked the Jesuit provincial superiors to warn Nagy against speaking out on social issues. Feeling unappreciated and in danger, in 1948 Nagy moved to Buenos Aires. He continued speaking out on social issues and became familiar with the teachings of liberation theology. As a result of his activity, the traditionalist South American church leadership accused Nagy of fostering revolutionary ideas, and he was sidelined by the church. Nagy had to give up trying to organize Argentinean poor youth, which caused him a crisis of faith. In 1948 he left the Jesuit Order, got married with a woman of Transylvanian origin, like himself, and had a daughter. Having left the Jesuits he continued to search for a socially conscious, intellectual, and philanthropic organization that would allow him to continue his work with the poor. His search led him to join the Freemasons, which gave him the idea to write and publish his first book, entitled Jesuitas y masones ['Jesuits and Freemasons'] in Spanish in 1963, and two years later in Hungarian as well. With this book Nagy wanted to debunk conspiracy theories, and eliminate the prejudices and mutual mistrust between the Church and the Freemasons. The book emphasized the importance of social work as central to both organizations. This book soon became a bestseller. A reviewer in the July 1966 of the Australian Free Hungary not only praised the book but also wrote that Hungarians should be proud that the dialogue between the Church and the Freemasons was begun by a Hungarian.

In 1967 Nagy started collecting material for a new book, Iglesia y Comunismo ['Egyház és kommunizmus' or 'Church and Communism'], in which he wanted to show the commonality between the Church and the post-Stalinist states. His main claim was that both organizations wanted to improve social welfare. On the one hand Nagy felt alienated from Argentinean society, and, on the other, his left-leaning writings aroused the interest of SIDE's (Secretaría de Inteligencia del Estado ['The State Intelligence Secretariat']) in him. Nagy was an active participant in Hungarian community life in Buenos Aires and a frequent visitor at the Hungarian Embassy. As of late 1966, tempted by the possibility that he would get both the publication of his books in Hungary and support for their foreign-language publication, Nagy became a secret collaborator with the Hungarian State Security Service. In 1968, with the help of the Service, Nagy and his family returned to Hungary. The family was given a luxurious apartment in Buda and a 3,000 HUF monthly payment from the Service. He got a job at the Akadémia publishing house, where he was assigned to a team working on a new literary encyclopedia.

Life in Hungary did not turn out as rewarding as Nagy had expected. The publication of his books proceeded very slowly, he was bored at his job, and his promotion in the State Security apparatus was blocked. He then returned to his unofficial diplomatic role using his Freemason connections to reconnect with the Vatican. He again wrote reports on Hungary for the Vatican as well as reports on the Congregatio Generalis for his Hungarian handlers. Although since 1950 Freemasonry was banned in Hungary, no action was taken against the Freemason lodges, and the Freemasons' clandestine meetings continued. Some of the meetings were even held in Nagy's 
house. Nagy reported to his handlers on the priests and South American diplomats he met, but he never reported on the Freemasons he met in Hungary.

In 1979 Nagy suffered a heart attack and died. His wife and daughter returned to Argentina. Summing up his life and activities it can be said that Nagy never gave up his Christian socialist ideas. The overarching goals and ideals in Nagy's life were his desire to play a role in improving the lives of the most downtrodden members of society and creating mutual understanding and acceptance between the Catholic Church and the changed post-WWII Hungary. The strengths of Éva Petrás' book about Nagy's life are that it follows a conflictridden, exciting life, and that throughout her book the author maintains a nonjudgmental and objective stance toward her subject of study. Throughout his life Töhötöm Nagy kept meticulous notes and diaries, which Petrás has checked against other primary sources to avoid the trap of accepting Nagy's self-justification. All this makes this book is a fascinating read, not only for historians, but also for anyone interested in looking behind the curtain (sometimes also meaning the Iron Curtain) and learn more on less-known figures in history and culture. 